NBER WORKING PAPER SERIES

\title{
NEW FACTS ABOUT FACTOR-DEMAND \\ DYNAMICS: EMPLOYMENT, JOBS \\ AND WORKERS
}

Daniel S. Hamermesh

Wolter H. J. Hassink

Jan C. van Ours

Working Paper No. 4625

\section{NATIONAL BUREAU OF ECONOMIC RESEARCH 1050 Massachusetts Avenue \\ Cambridge, MA 02138 \\ January, 1994}

We thank Frank den Butter for helpful comments, William Prat for computational assistance, and the Organization for Labor Market Research (OSA), The Hague, for the use of their data and for financial support. This paper is part of NBER's research program in Labor Studies. Any opinions expressed are those of the authors and not those of the National Bureau of Economic Research. 


\title{
NEW FACTS ABOUT FACTOR-DEMAND \\ DYNAMICS: EMPLOYMENT, JOBS \\ AND WORKERS
}

\begin{abstract}
We provide a unified discussion of the relations among flows of workers, changes in employment and changes in the number of jobs at the level of the firm. Using the only available set of data (a nationally representative sample of Dutch firms in 1988 and 1990) we discover that: 1) Nearly half of all hiring is by firms where employment is not growing; 2) Over half of all firing is by firms that are not contracting; 3 ) Most firing is by firms that are also hiring; 4) Flows of workers within firms are small compared to flows into and out of firms; and 5) Accounting for simultaneous creation and destruction of jobs within firms adds roughly 15 percent to estimates of economywide job creation and destruction. The results imply that macroeconomic fluctuations can have substantial effects beyond those indicated by net employment changes at the firm level, and that studies of dynamic factor demand must account for variations in gross flows of workers.
\end{abstract}

Daniel S. Hamermesh Department of Economics University of Texas Austin, TX 78712 and NBER
Wolter H. J. Hassink

Vrije Universiteit

Amstendam

THE NETHERLANDS
Jan C. van Ours Tinbergen Institute Amsterdam/Rotterdam THE NETHERLANDS 


\section{Introduction}

Various terms have been used to describe, summarize and analyze the macroeconomic dynamics of labor demand, including "job creation/destruction," "employment growth/decline," and "hiring/firing." Our purposes here are to sort out differences in these terms and examine how the concepts should be viewed from the perspective of the individual firm. The discussion alone should demonstrate that great care is required in using the various terms, as they mean very different things and have different implications for analyzing labor-market adjustment and the impact of policies. We demonstrate some aspects of their importance using the first available data set that allows comprehensive measures of job creation and types of labor mobility.

\section{Alternative Concepts of Demand Dynamics}

Underlying the entire discussion are two fundamental issues: 1) What patterns of changes in staffing at the firm level might be generating macroeconomic fluctuations? and 2) What microeconomic forces produce these changes? The latter issue has been analyzed in the considerable literature dealing with the nature and size of adjustment costs. Substantial interesting work has recently gone beyond standard models of convex adjustment costs to analyze the possible existence of lumpy costs at the micro level (Hamermesh, 1989; Caballero et al, 1993) and their usefulness in explaining aggregate 
fluctuations (Caballero and Engel, 1993). Other research has attempted to infer what generates these costs (Hamermesh, 1993b).

We do not consider the second issue. Our interest here is not in explanation but rather in illustrating and clarifying what occurs at the firm/establishment level. Are job creation, hiring and employment growth interchangeable terms for the same phenomenon? Are job destruction, firing and employment decline interchangeable? What do we mean by job creation?

The terms job creation and destruction have been applied recently in the macroeconomic literature (e.g., Davis and Haltiwanger, 1990). Though it does not use the term, what this literature really discusses are simultaneous positive and negative firm- (or plant - ) level net employment changes. Substantial empirical work (e.g., Leonard, 1987; Dunne et al, 1989; and Davis and Haltiwanger, 1992) demonstrates that employment falls (rises) in a large fraction of the micro units within a narrowly defined aggregate where the net change in employment is positive (negative). ${ }^{1}$ That interfirm (or interplant) reallocation is important within an aggregate is useful for demonstrating how changes in the dispersion of demand shocks can affect macroeconomic adjustment.

Even assuming that labor is homogeneous, concentration on net employment changes ignores much of the potentially important adjustment

'See Hamermesh (1993a, Chapter 4) for a summary and critical discussion of this literature. 
costs that might be generated by demand shocks. One can easily imagine a firm where there is no net change in employment over some period, but where, for example, all five assistant professors of economics quit and five new ones are hired to replace them. Net employment change is zero; the measured interfirm reallocation is zero; and no jobs are destroyed or created. Yet clearly the costs to the firm are nonzero; and the costs to society are also much different from those that would have arisen if no quits had occurred. The net change in employment in an establishment can be decomposed in great detail as:

(1) $\Delta \mathrm{E} \equiv \mathrm{NH}+\mathrm{R}+\mathrm{TI}-\mathrm{Q}-\mathrm{F}-\mathrm{D}-\mathrm{TO}$,

where NH are new hires; $\mathrm{R}$ are rehires; TI are transfers from other plants in the firm; $Q$ are quits; $F$ are fires (layoffs in American terminology); $D$ are discharges for cause; and TO are transfers to other plants in the firm. ${ }^{2}$

Some attention has been given to (1). Burgess and Nickell (1990) examined aggregates of accessions (the first three terms) and separations (the last four terms); and Hamermesh (1993b) considered the pattern of hires, quits and net employment change for several establishments. We do not know, though, the extent to which establishments or firms can be classified using (1) into those that are growing and hiring, and declining and firing; or whether

${ }^{2}$ This is essentially the decomposition used in the establishment data collected by the U.S. Bureau of Labor Statistics from 1958 through 1981. 
hiring and/or firing are activities that are only loosely related to net employment changes. That is, does growth in employment mean that the firm is in a "hiring regime" (Lockwood and Manning, 1993)? Does a drop in employment imply a "firing regime?" The first specific question we examine is what net changes in employment in a firm or establishment imply about the type and extent of flows of workers into and out of it.

These distinctions are important because the assumptions underlying theories of the dynamics of labor demand equate expansion with hiring (and contraction with firing). The locus classicus in this area (Sargent, 1978) presents a rational-expectations approach to the firm's net change in employment. The vast subsequent literature in macroeconomics essentially ignores the possibility that negative net changes in employment may not only occur when firms fire workers, but may instead reflect substantial hiring. The "European approach" (e.g., Nickell, 1986) does treat the firm's decision in terms of some of the gross flows in (1). But this approach has had little impact on the discussion in macroeconomics, perhaps because data on these flows are very difficult to obtain.

With heterogeneous workers and jobs the distinction between job creation/destruction and hiring/firing/employment changes is essential. If, for example, the firm fires five assistant professors of sociology and replaces them with five assistant professors of economics, its costs differ from those in the example above, where economists who quit were replaced by others. If the 
firm abolishes one vice-presidential position and transfers the incumbent to a newly-created other such position, its costs will be greater than if no changes occurred. Most important, in both of these cases jobs are created (and an equal number are destroyed), even though there is no firm-level net employment change.

Figure 1 offers a complete taxonomy of the dynamics of labor demand for a single-plant firm. ${ }^{3}$ Every worker in the firm fills a job. In Period $t$ there are $J_{t}$ jobs. Between times $t$ and $t+1$ some jobs are destroyed, and some workers whose jobs were not destroyed either separate or move internally to existing or newly-created jobs. Some of the separated workers were fired, either because of incompetence or because their jobs were destroyed. A flow of newly-hired workers takes the remaining newly-created jobs or fills the positions vacated by quitters.

The simplest concept illustrated in Figure 1 is the same net employment change, $\Delta E$, as in (1), which by definition equals $\mathrm{J}_{t+1}-\mathrm{J}_{\mathrm{t}}$. The second concept is the firm-level net employment change, $\Delta \mathrm{E}^{+}+\Delta \mathrm{E}^{-}$, which measures the sum of all jobs created and destroyed (if one ignores shifts of jobs within the firm). This is the now-standard calculation based on observations on plants or firms between two time periods. The third measure,

${ }^{3}$ The figure is simplified by omitting vacant jobs. It is based on people and jobs and necessarily ignores intensity of effort (including hours worked in each job and effort per hour). 
which we denote by $\mathrm{J}^{\mathrm{C}}+\mathrm{J}^{\mathrm{D}}$ (jobs created plus jobs destroyed) and call job turnover, adds gross shifts in jobs within the firm to the second measure: Thus just as $\Delta \mathrm{E}^{+}+\Delta \mathrm{E}^{-}$departs from $\Delta \mathrm{E}$ by adding interfirm gross job creation and destruction within an aggregate of firms, $\mathrm{J}^{\mathrm{C}}+\mathrm{J}^{\mathrm{D}}$ departs from $\Delta \mathrm{E}^{+}+\Delta \mathrm{E}^{-}$by adding intrafirm gross job creation and destruction in the aggregate of jobs within individual firms.

All three of these measures ignore the identity of the workers. All, including the third one which is novel here, are based on positions, not people. The fourth measure is labor turnover, based on total hires $H$ and separations $\mathrm{X}$. The relations among the four terms are:

$$
\Delta \mathrm{E} \leq \Delta \mathrm{E}^{+}+\Delta \mathrm{E}^{-} \leq \mathrm{J}^{\mathrm{C}}+\mathrm{J}^{\mathrm{D}} \leq \mathrm{H}+\mathrm{X} .
$$

Obviously, net employment change is the same no matter on which concept it is based:

$$
\Delta \mathrm{E} \equiv \Delta \mathrm{E}^{+}-\Delta \mathrm{E}^{-} \equiv \mathrm{J}^{\mathrm{C}}-\mathrm{J}^{\mathrm{D}} \equiv \mathrm{H}-\mathrm{X} .
$$

It is difficult to do justice to the complexity of Figure 1 in theoretical or empirical research. Even what we have called the European approach assumes that the firm is never hiring when it is firing workers, and viceversa. That assumption is required by profit maximization in the presence of the homogeneous work force that the models always assume. In a world of heterogeneous labor simultaneous hiring and firing is possible in response to relative demand or cost shocks. Whether this simultaneity is empirically important is the second specific question investigated in the next section. We 
analyze both the simultaneity of hiring and firing and the extent to which heterogeneity causes $\mathrm{J}^{C}+\mathrm{J}^{\mathrm{D}}$ to exceed $\Delta \mathrm{E}^{+}+\Delta \mathrm{E}^{-}$.

The possible coexistence of hiring and firing in a firm has implications for macroeconomic adjustment. The employment reallocation generated by macroeconomic shocks may greatly exceed the interfirm (or interplant) reallocation that has been the focus of so much recent research. The greater intrafirm and intraplant reallocation are, the greater are the implicit costs of changing output levels. The cost to the firm of a negative macroeconomic shock is indicated not by the loss in employment, but by the costs of hiring and firing that may accompany the shock. Because hiring and firing may occur simultaneously, these costs cannot be inferred simply by summing up hires in firms that are only hiring, and fires in those that are only firing. The subtleties of analyzing employment fluctuations at the macro level are even greater than moving from aggregating firms' net employment changes to aggregating their gross changes would suggest.

\section{Estimates of the Component Flows of Labor Demand}

In this Section we show that the distinctions between gross and net flows are important empirically and should condition how we discuss labormarket dynamics. We make no attempt to model the determinants of these flows or their interrelationships. Rather, using the first broad-based random sample that allows the analysis of net employment and job changes and flows 
of workers at the firm level, we inquire about the definitional and conceptual issues raised in the previous section.

This data set, whose inclusion of information on types of flows of workers and on internal mobility makes it unique for any industrialized economy, is based on two surveys by the Organization for Labor Market Research (OSA) of the Netherlands. ${ }^{4}$ The surveys are of organizations, which we refer to as firms, and are representative of all industries (including government and education) in the Netherlands in 1988 and 1990. The samples are stratified according to area of economic activity and size of the firm (10$49,50-99$, and $100+$ employees), with firms of fewer than 10 employees excluded. While the data are representative only of one small economy, the Netherlands is highly advanced and typical in its mix of industries. Moreover, this data set, unlike many of those used to study factor-demand dynamics that are restricted to the small and decreasingly important manufacturing sector, covers the entire economy.

Each survey uses two questionnaires. The first, which is administered by enumerators, concerns qualitative characteristics and financial data; the

${ }^{4}$ Two studies (Cramer and Koller, 1988; Lane et al, 1993) have used establishment data to examine employment changes and worker flows (though none has accounted for internal mobility, and none has information on types of flows of workers). There have also been efforts to draw inferences from the longitudinal panels of establishments in conjunction with data on workers from household surveys (e.g., Boeri, 1992). 
second concerns administrative information. The mail responses to this second questionnaire come some time after the first questionnaire is answered and have a nonresponse rate of $20-25$ percent. In 1988 the sample consists of 2041 firms, in 1990 of 2017 firms. The firms included in each survey contain roughly 3 percent of total employment in the Netherlands. The surveys were set up as a panel, but a large number of the 1988 firms did not cooperate in 1990, had a substantial change in activities or merged. 1190 firms responded in both years.

Removing those firms that lack essential information (for example, answers on the second questionnaire) leaves a sample of 1159 firms from the 1988 survey and 1045 firms from the 1990 survey. The results in Tables 1-4 and Figures 2 are based on the pooled sample of these 2204 observations; the panel of 558 firms with complete responses is the basis for Table 5; while Tables 6 and 7 (illustrating Figure 1) are based only on the data for 1990. Other than in Tables 6 and 7 the information we present is weighted by sector and firm size to be representative of the entire Dutch economy. Definitions of the main variables are presented in Appendix A. Employees with temporary contracts shorter than one year are excluded.

A. Net Employment Changes and Flows of Workers

Table 1 presents summary statistics for the pooled sample. The average annual hiring rate is 12.4 percent. The outflow rate is 11.8 percent, of which the firing rate is 1.5 percent and the quit rate is 8 percent (and the 
rest miscellaneous outflows). The average annual internal mobility rate is $\mathbf{3 . 3}$ percent.

Table 1 divides the pooled sample into firms with growing, stable and declining employment. Unsurprisingly, the hiring rate decreases as employment growth moves from positive to negative. Still, hiring rates in firms with declining employment average 5.9 percent. Most important, calculations based on the table show that only $\mathbf{5 8}$ percent of all hires occur in firms that are expanding. The firing rate where employment is declining is higher than where it is increasing or stable. Firms with expanding employment still fire 1.1 percent of their workers each year, though; and only 40 percent of all fires occur in firms that are contracting.

Quit rates in firms with increasing employment are somewhat less than in firms with decreasing or stable employment, but the differences in these average are quite small. The quit rate seems relatively unaffected by conditions within the firm (presumably responding more to general labormarket conditions). Internal mobility rates are highest among growing firms, suggesting that the expansion of employment does lead to greater opportunities for incumbent employees.

Figure 2 presents more detail about the relationships between rates of flows of workers and employment growth. Firms are classified into growth categories ranging in steps of two percentage points from -28 percent to +28 percent. The left - and right - most bars represent the average rates from the 
tails and contain 0.6 percent and 1.5 percent of the (employment-weighted) firms respectively. Figure $2 a$ shows that hires occur even at large negative employment growth. The hiring rate is roughly stable at 5 to 8 percent where employment is declining, regardless of the size of the decline. Among expanding firms there is a clear positive correlation between employment growth and the hiring rate.

Figure $2 \mathrm{~b}$ shows that the relationship between the firing rate and employment growth is the mirror image of Figure 2a. The firing rate is quite stable at about 1 percent where employment is growing. Where employment is declining, the firing rate is greater the larger is the drop in employment.

Figure $2 c$ graphs the quit rate by employment change. As was obvious in Table 1, there is no strong correlation between the two. Figure $2 \mathrm{~d}$ shows that the average internal mobility rate also does not vary much with employment growth. If internal mobility were important in the reshuffling of employment, we would see a U-shaped relationship between it and employment growth. Figure $2 \mathrm{~d}$ gives at most only a very slight hint of this. Where employment is growing very rapidly, though, reshuffling is substantial: The internal mobility rate is highest among firms growing at least 24 percent per year.

Table 1 and Figure 2 demonstrate the well-known fact that there is substantial turnover of workers at the firm level. They also produce several novel conclusions. 1) Most important, these flows are large even in firms 
where net employment changes are small. 2) Hiring is not restricted to firms with expanding employment (mostly because of the very high rate of quitting). 3) Firing is not restricted to firms with declining employment. 4) Internal mobility is low, below the average hiring rate, even in firms with declining employment. Most workers enter their jobs directly from outside the firm, while internal mobility chains (movements along Dunlopian, 1957, job ladders) are relatively few.

Consider these issues in more detail. Table 2 groups firms according to hiring and firing status and whether employment is growing, stable and declining. The table shows that one quarter of the firms in our sample did not alter employment in a given year. The fractions of firms with decreasing or increasing employment are about the same. Most of the firms ( 83 percent) are hiring, either with (21.6 percent) or without (61.3 percent) firing. Together with the observation that only 2.6 percent of firms fire without hiring, this demonstrates that most firing is done by firms that are also hiring.

Table 3 details the relationships among hires, fires and quits. The four possible combinations of hiring and firing are related to the presence or absence of quits. To what extent is the combination of firing and hiring related to the existence of quits? Are fires 'really' necessary, or could a cut in employment also have been accomplished by quits? Since Table 1 showed that $\mathrm{Q}$ and $\Delta \mathrm{E}$ are very weakly correlated, it is reasonable to interpret the results as more than a reflection of the relation between $\Delta \mathrm{E}$ and hires. Quits 
occur in $\mathbf{7 8 . 5}$ percent of firms. The combination of hiring and firing without quits occurs in only 2.9 percent of the sample. We observe simultaneous hiring and firing in the presence of quits in 18.7 percent of the firms; and, unsurprisingly, there is a positive relation between quits and the propensity to hire. While large rates of quitting allow firing rates to be kept far below hiring rates, in some firms shocks are sufficiently large that they cannot be met solely by reliance on quits.

\section{B. Heterogeneous Workers and Firms, and Job Creation}

Table 4 examines whether simultaneous hiring and firing can be attributed to one source of heterogeneity in the work force, the distinction between white-collar (WC) and blue-collar (BC) workers. If, for example, employment declines among white-collar workers, while quitters are bluecollar workers who must be replaced, we would observe both hiring and firing at the firm level. Consistent with Table 2, 78.4 percent of firms are in the top row or first column, either hiring and not firing, or vice-versa. Among the 21.6 percent of firms that are hiring and firing, only 1.1 percent of all firms are firing only one type of worker and hiring only the other. By far the most common pattern among this 21.6 percent of firms is hiring and firing of bluecollar workers (13.4 percent of firms). Table 4 shows clearly that heterogeneity across broadly-defined occupation accounts for only a small part of the surprisingly common hiring in the presence of firing. 
Table 5 examines the extent that firms can be classified as remaining in the same regime over time (e.g., expanding and hiring, declining and hiring, etc.) by presenting data describing the panel of firms. Roughly 14 percent of firms are declining in both years; and another 14 percent are growing in both years. A large majority, though, are growing in one year and stable or declining two years later. Probably most interesting is the relative lack of persistence in hiring. Firms with stable employment in both years that are hiring in the first year have only a .54 probability of hiring in the second year. Similarly, hiring behavior among firms that are declining in both years is quite variable over time. While there is some persistence in hiring among continuously growing and stable firms, even they vary their hiring greatly. The implied on-off behavior may reflect the existence of nonconvex costs of hiring.

Table 6 presents estimates of the flows in Figure 1. For each firm the survey provides information on the last worker in the flow of hires, in the outflow and in the internal flow. The firms are asked whether the worker obtained a newly-created job (for hires and internal flows) and whether the worker left a job that was not refilled (for outflows and internal flows). Aggregation of workers over the sample yields estimates of the hiring rates $\mathrm{H} 1$ and $\mathrm{H} 2$ (to newly-created and existing jobs), estimates of outflow rates X1 and $\mathrm{X} 2$ (from existing and destroyed jobs) and of the internal mobility rates IM1 through IM4 (from existing/destroyed to existing/newly-created jobs). 
The information is not weighted, because weighting would bias the estimates of the fractions. ${ }^{5}$ For this reason and because the data cover only 1990 the estimates do not correspond to their counterparts in Table 1.

The distinction between existing and newly-created jobs in this taxonomy generates several interesting observations. Most important, the very large majority of mobility is to and from existing jobs. Most outflows, inflows and internal flows represent reshuffling of people into and out of positions whose existence continues.

The most important use of the taxonomy in Figure 1 is its illustration of the inequalities in (2). This is presented in Table 7, again with unweighted data. As in all other studies firm-level net employment change dwarfs average net employment change (6.2 versus 1.8 percent). Including intrafirm gross job creation and destruction to allow the calculation of $\mathrm{J}^{\mathrm{C}}+\mathrm{J}^{\mathrm{D}}$ raises the estimate of job turnover to 7.0 percent, roughly 15 percent above what the standard measure, $\Delta \mathrm{E}^{+}+\Delta \mathrm{E}^{-}$, would suggest. This is important; but it is small enough that the existence of simultaneous creation and destruction of jobs within firms should not greatly alter our views about the relative

${ }^{5}$ The raw estimates imply $\mathrm{J}^{\mathrm{C}}-\mathrm{J}^{\mathrm{D}}=2.6$ percent, which does not satisfy the identity (3). To obtain the identity we adjusted $\mathrm{H} 1$ and $\mathrm{X} 2$ by adding respectively $\delta_{1} \mathrm{H} 1$ and $\delta_{2} \mathrm{X} 2$. The optimal weights $\delta_{i}$ are those that minimize the quardratic loss function $\delta_{1}^{2}+\delta_{2}^{\frac{2}{2}}$, subject to $\left[1+\delta_{1}\right] \mathrm{H} 1-\left[1+\delta_{2}\right] \mathrm{X} 2=$ $\mathrm{H}$ - X + IM3 - IM4. 
magnitudes of aggregate employment change and firm-level net employment change.

How can we rationalize this Subsection's finding that simultaneous creation and destruction of jobs within the firm is small with the result of the previous Subsection that most of the firms that are firing are also hiring? One possibility consistent with the data is that most of the jobs that are vacated by fired workers are filled by workers who are hired to replace them in jobs that continue. With a 1.5 percent firing rate in the pooled data, and with $\mathrm{J}^{\mathrm{D}}$ $\Delta \mathrm{E}^{-}=.4$, one might infer that roughly a third of workers who are fired vacate jobs that disappear, while two-thirds of fired workers are replaced by hires.

IV. Conclusions

We have investigated whether using the terms job creation/destruction and hiring/firing interchangeably makes sense in light of the first available set of establishment data on employment levels and worker flows by type to, from and within firms. The terms are definitely not interchangeable. Hiring is not restricted to firms with expanding employment; over 40 percent of hiring is done by firms that are not growing. Firing is not restricted to firms with declining employment; the majority of firing is done by firms that are not declining. It is clear that jobs are being destroyed by firms doing substantial hiring, and that they are being created by firms that are 
firing. This result cannot be explained by heterogeneity arising from the presence of blue - and white-collar workers.

The huge difference between aggregate net employment change and firm-level net employment change that has been noted frequently in the recent literature is enlarged only somewhat when simultaneous job creation and destruction within firms is accounted for. Obviously this conclusion depends on how one defines jobs: We could easily count any slight change in duties (e.g., switching from teaching two courses and doing research to one course and somewhat more research) as the creation and destruction of jobs. Nonetheless, using the job classifications that employers themselves use, our results suggest that ignoring the heterogeneity arising from job creation/destruction within firms does not detract greatly from our ability to analyze macroeconomic fluctuations that are related to interfirm heterogeneity.

That hiring and firing occur simultaneously within the same firm suggests that a fundamental problem exists with all studies of dynamic labor demand based on homogeneous labor. The heterogeneity of jobs implied by this simultaneity means that we cannot infer adjustment costs by examining patterns of adjustment of aggregates of all workers. Even if employment is unchanged (in the context of models based on levels), and even if we observe hiring (in the context of the models based on flows of workers), we must take into account the frequently simultaneous existence of employer-initiated layoffs that themselves add to adjustment costs. 
The demonstration over the last decade that beterogeneity in employment growth among firms and establishments within narrowly-defined industries is immense has been a fundamental contribution to our understanding of the microeconomic bases of macroeconomic change. Here we have demonstrated that there is a concomitant heterogeneity in flows of workers into and out of the firm, and through and between jobs, among firms whose employment is changing at identical rates. Moreover, these flows are substantial. These facts suggest that an important step will be to analyze how the two types of interfirm heterogeneity interact to alter macroeconomic outcomes. 


\section{REFERENCES}

Tito Boeri, "Why Are Establishments So Heterogeneous?" Unpublished paper, OECD, 1992.

Simon Burgess and Stephen Nickell, "Turnover in U.K. Manufacturing," Economica, 55 (1990): 295-318.

Ricardo Caballero and Eduardo Engel, "Microeconomic Adjustment Hazards and Aggregate Dynamics," Quarterly Journal of Economics, 108 (1993): $359-84$.

,--------------------------------- and John Haltiwanger, " Aggregate Employment Dynamics: Building from Microeconomic Evidence," paper presented at Workshop on Labour Market Dynamics and Employment Fluctuations, Sorbonne, Paris, September 1993.

Ulrich Cramer and Martin Koller, "Gewinne und Verluste von Arbeitsplātzen in Betrieben--der "Job-Turnover" -Ansatz," Mitteilungen aus der Arbeitsmarkt - und Berufsforschung, 21 (1988): 361-377.

Steve Davis and John Haltiwanger, "Gross Job Creation and Destruction: Microeconomic Evidence and Macroeconomic Implications," NBER Macroeconomics Annual, 5 (1990): 123-68.

,-------------------------------- , Gross Job Creation, Gross Job Destruction and Employment Reallocation, " Quarterly Journal of Economics, 107 (1992): 819-63.

John Dunlop, "The Task of Contemporary Wage Theory, " in George Taylor and Frank Pierson, eds., New Concepts in Wage Determination. New York: McGraw-Hill, 1957.

Timothy Dunne, Mark Roberts and Larry Samuelson, "The Growth and Failure of U.S. Manufacturing Plants, " Quarterly Journal of Economics, 104 (1989): 671-98.

Daniel Hamermesh, "Labor Demand and the Structure of Adjustment Costs," American Economic Review, 79 (1989): 674-89.

Press, 1993, a.

Labor Demand. Princeton University 
------------ , "Labor Demand and the Source of Adjustment Costs," NBER Working Paper No. 4394, July 1993, b.

Julia Lane, David Stevens and Alan Isaac, "How Do Firms Treat Workers? Worker Turnover at the Firm Level," unpublished paper, American University, October 1993.

Jonathan Leonard, "In the Wrong Place at the Wrong Time," in Kevin Lang and Jonathan Leonard, eds., Unemployment and the Structure of Labor Markets. New York: Basil Blackwell, 1987.

Ben Lockwood and Alan Manning, "The Importance of Kinked Adjustment Costs: Some Evidence from U.K. Manufacturing," in Jan van Ours, Gerard Pfann and Geert Ridder, eds. Labor Demand and Equilibrium Wage Formation. Amsterdam: North-Holland Press, 1993.

Stephen Nickell, "Dynamic Models of Labour Demand," in Orley Ashenfelter and Richard Layard, eds., Handbook of Labour Economics. Amsterdam: North-Holland Press, 1986.

Thomas Sargent, "Estimation of Dynamic Labor Demand Schedules under Rational Expectations," Joumal of Political Economy, 86 (1978): 1009-44. 


\section{Appendix A. Definition of Variables}

E: "How many workers were employed in your organization in December 1988 (1990) (no temporary workers). This concerns the number of employees irrespective of the number of hours worked". In the 1988 wave $\mathrm{E}$ is observed for 1988 and 1986. Employment for December 1987 and December 1989 are constructed by means of the hires $(\mathrm{H})$ and the outflow $(X)$ of employees in the next year: $E_{t-1}=$ $E_{t}-H_{t}+X_{t}$.

H: $\quad$ "How many employees entered your organization in 1988 (1990), including employees with a probationary period, excluding employees with a temporary contract shorter than one year?"

X: "How many employees left your organization in 1988 (1990), excluding employees with a temporary contract shorter than one year." $X$ is divided into the number of employees who left the organization for the following reasons:

- pension, early retirement, death;

- outflow because of disability;

- firing;

- quit;

- end of temporary contract with a duration $>$ one year.

IM: "How many employees changed function and/or changed department within the organization?" 
Figure 1. Heterogeneous Jobs and Workers in the Firm

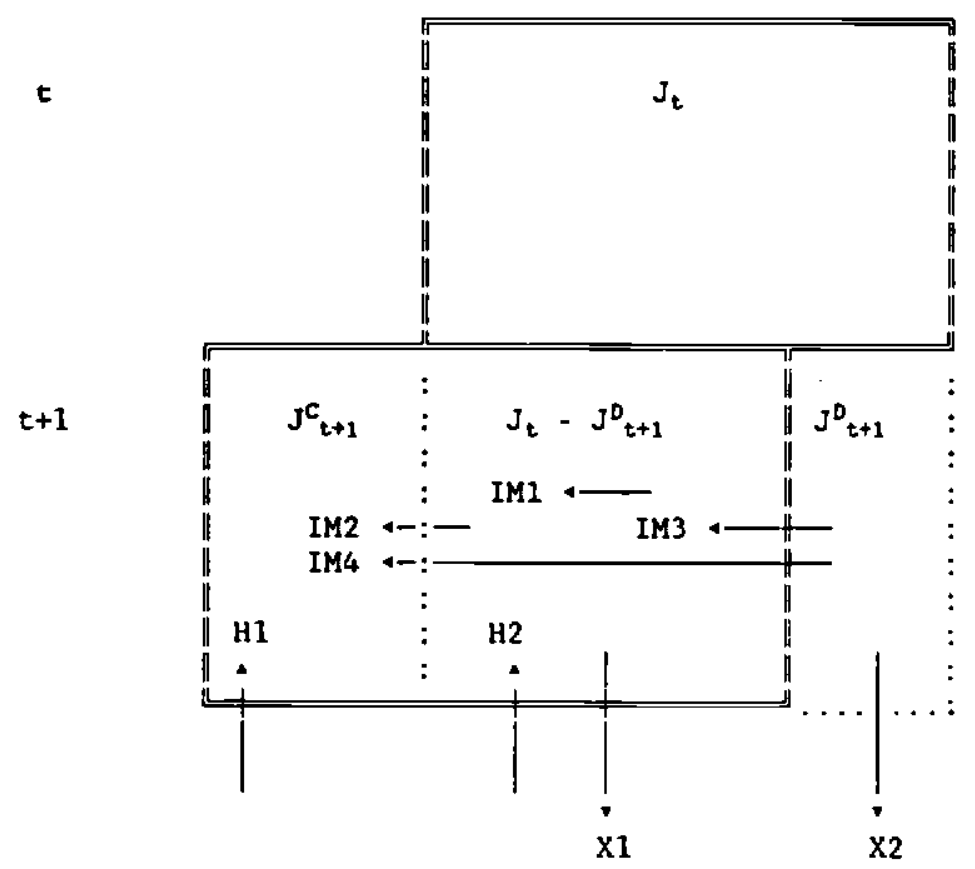

Stocks

$$
\begin{aligned}
& \mathrm{J}=\text { jobs } \\
& \mathrm{J}^{\mathrm{C}}=\text { (newly) created jobs } \\
& \mathrm{J}^{\mathrm{D}}=\text { destroyed jobs }
\end{aligned}
$$

\begin{tabular}{|c|c|}
\hline HI & $=$ hires to (newly) created jobs \\
\hline $\mathrm{H} 2$ & $=$ hires to existing jobs \\
\hline$X 1$ & $=$ outflow from existing jobs \\
\hline $\mathrm{X} 2$ & from destroyed jobs \\
\hline IMI & mobility between existing \\
\hline IM2 & $\begin{aligned}= & \text { internal mobility from existing jobs to } \\
& \text { (newly) created jobs }\end{aligned}$ \\
\hline IM3 & $\begin{aligned}= & \text { internal mobility from destroyed } \\
& \text { to existing jobs }\end{aligned}$ \\
\hline IM4 & $\begin{aligned}= & \text { internul mobility from destroyed jobs } \\
& \text { to (newly) created jobs }\end{aligned}$ \\
\hline
\end{tabular}

\section{Flows}


Flgure 2a. Hlring Rate by Growth of Employment

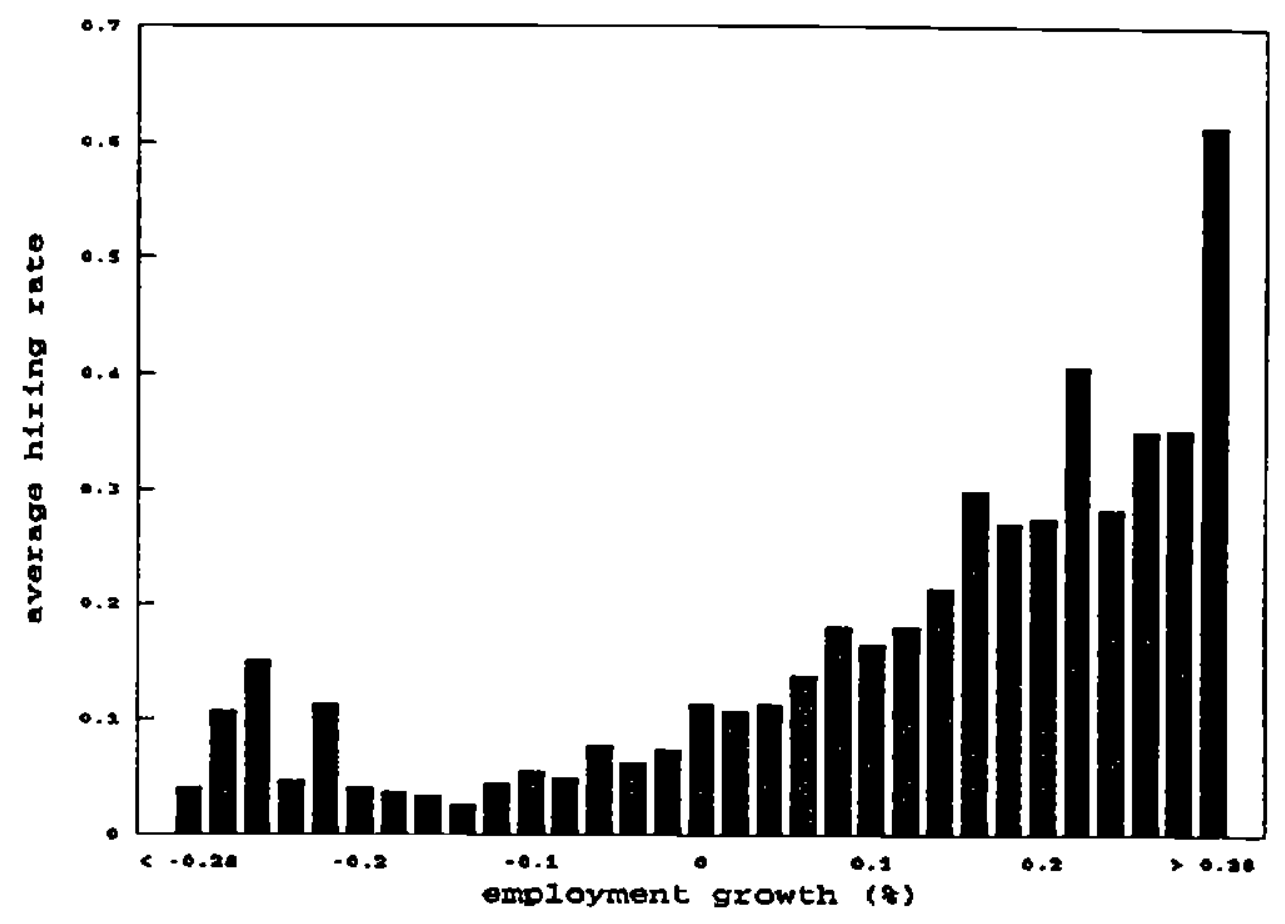


Figure 2b. Firing Rate by Growth of Employment

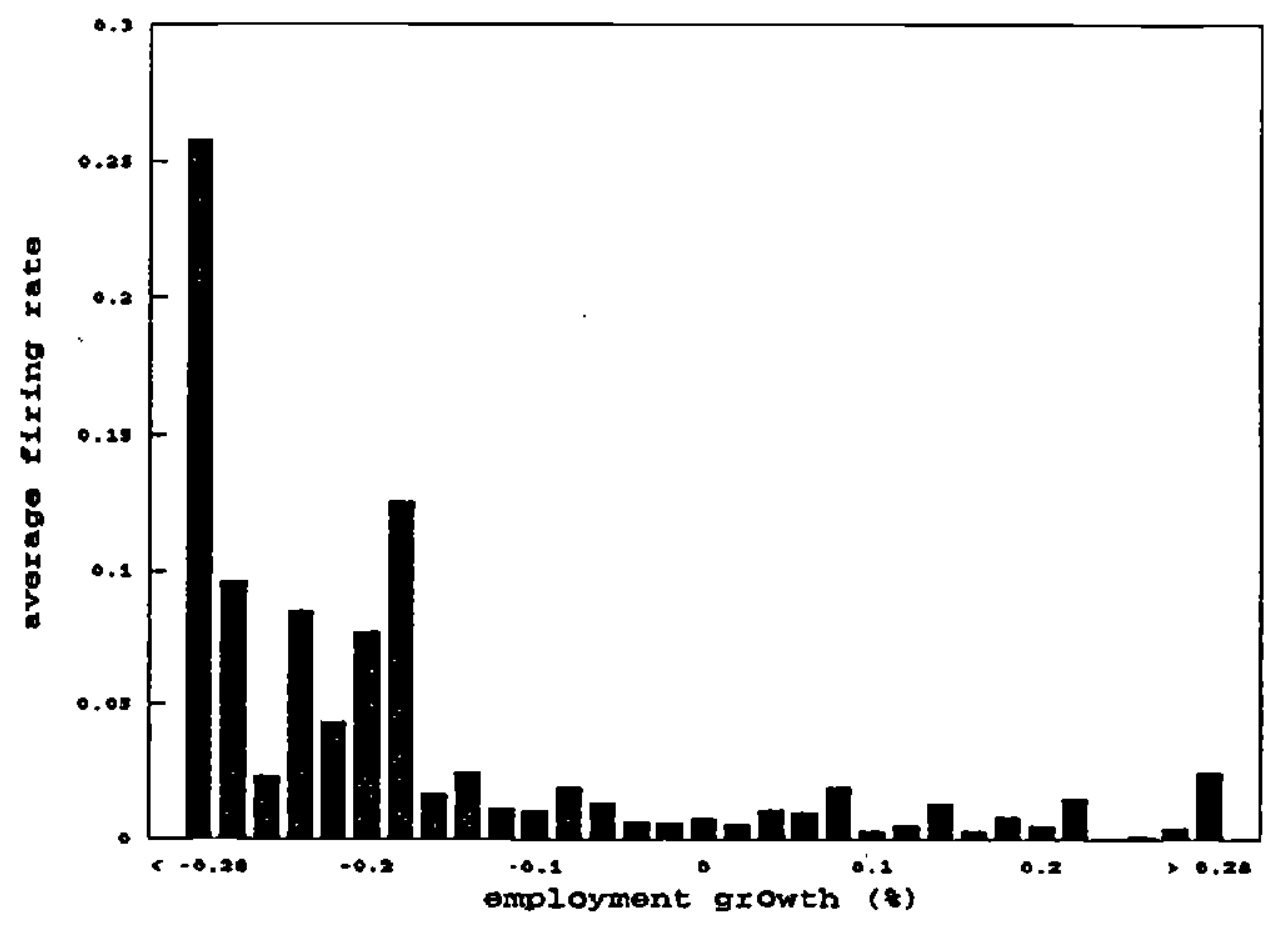


Figure 2c. Quit Rate by Growth of Employment

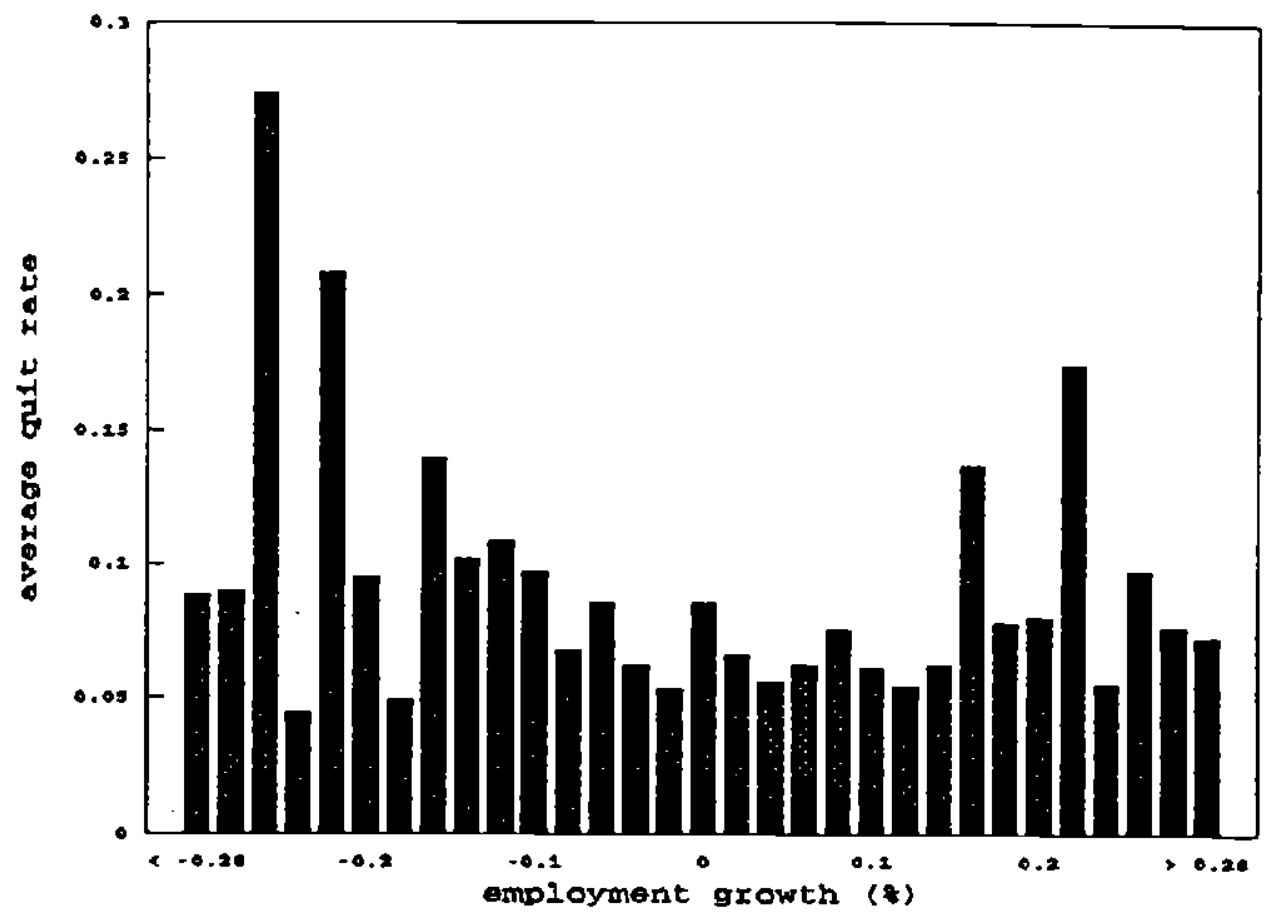


Figure 2d. Internal Mobility Rate by Growth of Employment

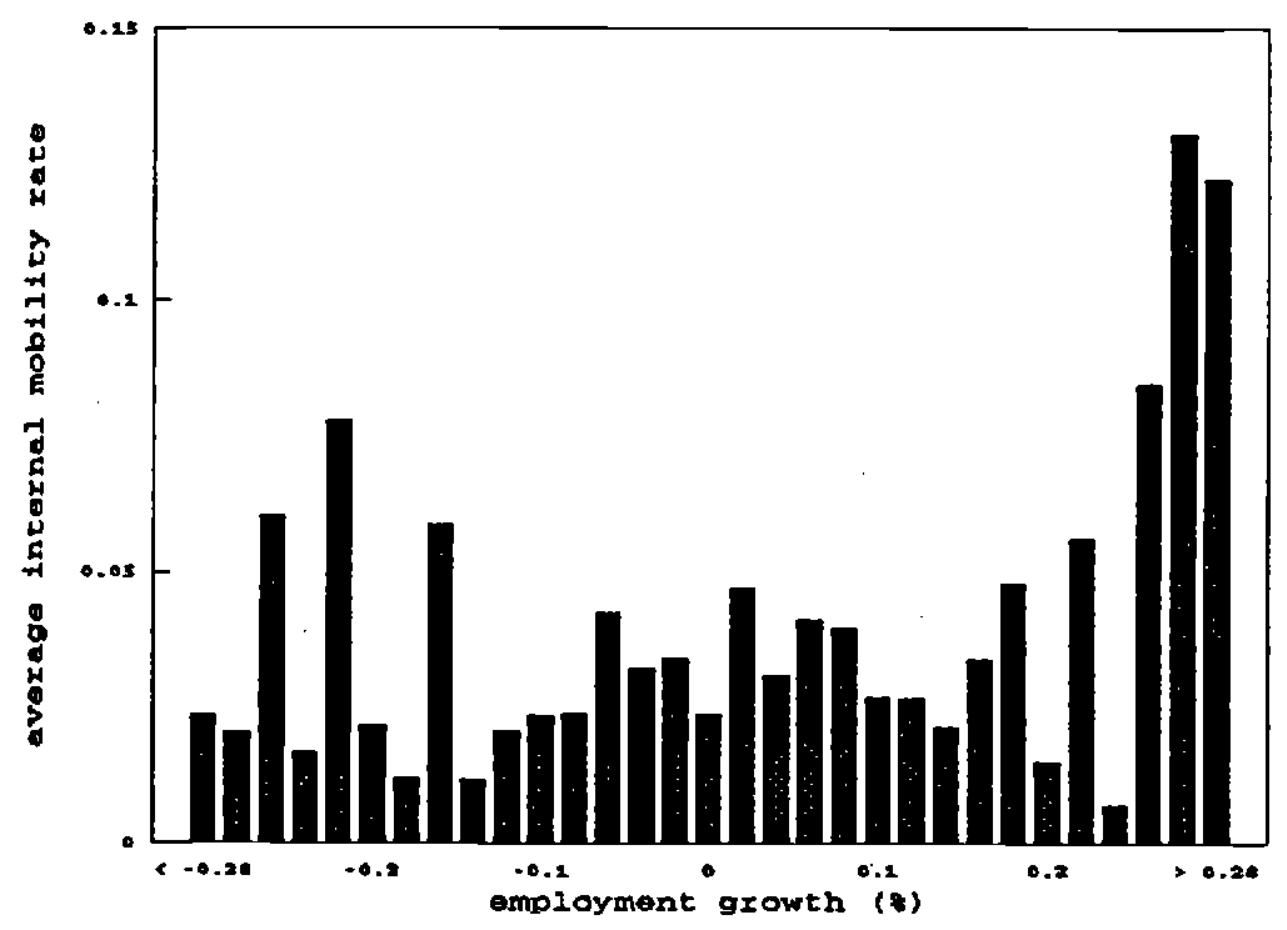


Table 1. Means (standard deviations) of Hires, Outhows, Fires, Quits and Internal Mobility, 1988 and 1990 (percent of employment)

\begin{tabular}{|c|c|c|c|c|c|c|}
\hline & $\mathrm{H}_{\mathrm{t}}$ & $x_{t}$ & $F_{1}$ & $Q_{1}$ & $\mathrm{IM}_{\mathrm{t}}$ & $\mathbf{N}$ \\
\hline $\begin{array}{l}\Delta \mathrm{E}>0 \\
\Delta \mathrm{E}=0 \\
\Delta \mathrm{E}<0\end{array}$ & $\begin{array}{c}20.3(14.2) \\
11.3(13.8) \\
5.9(7.0)\end{array}$ & $\begin{array}{l}9.8(7.9) \\
11.3(13.8) \\
13.9(9.7)\end{array}$ & $\begin{array}{l}1.1(2.9) \\
0.8(3.0) \\
2.3(6.4)\end{array}$ & $\begin{array}{l}7.0(7.0) \\
8.6(12.1) \\
8.4(7.8)\end{array}$ & $\begin{array}{l}4.2(8.1) \\
2.4(6.4) \\
3.0(5.7)\end{array}$ & $\begin{array}{l}890 \\
367 \\
947\end{array}$ \\
\hline Total & $12.4(13.4)$ & $11.8(10.0)$ & $1.5(4.7)$ & $8.0(8.4)$ & $3.3(7.0)$ & 2204 \\
\hline
\end{tabular}

Table 2. Hires, Fires and Employment Change, 1988 and 1990 (percent of firms)

\begin{tabular}{lcccc} 
& $\Delta \mathrm{E}<0$ & $\Delta \mathrm{E}=0$ & $\Delta \mathrm{E}>0$ & Total \\
\hline $\mathrm{H}=0, \mathrm{~F}=0$ & 9.9 & 4.6 & 0.0 & 14.5 \\
$\mathrm{H}=0, \mathrm{~F}>0$ & 2.6 & 0.0 & 0.0 & 2.6 \\
$\mathrm{H}>0, \mathrm{~F}=0$ & 16.6 & 17.5 & 27.2 & 61.3 \\
$\mathrm{H}>0, \mathrm{~F}>0$ & 9.5 & 4.0 & 8.1 & 21.6 \\
Total & 38.6 & 26.1 & 35.3 & 100.0 \\
\hline
\end{tabular}

Table 3. Hires and Fires by Quit Rate, 1988 and 1990 (percent of firms)

\begin{tabular}{lccc} 
& $Q=0$ & $Q>0$ & Total \\
\hline$H=0, F=0$ & 7.1 & 7.4 & 14.5 \\
$H=0, F>0$ & 1.6 & 1.0 & 2.6 \\
$H>0, F=0$ & 9.9 & 51.4 & 61.3 \\
$H>0, F>0$ & 2.9 & 18.7 & 21.6 \\
Total & 21.5 & 78.5 & 100.0 \\
\hline
\end{tabular}


Table 4. Blue- and White-collar Hires and Fires, 1988 and 1990 (percent of firms)

\begin{tabular}{|c|c|c|c|c|c|}
\hline Fires & $\begin{array}{l}B C=0 \\
W C=0\end{array}$ & $\begin{array}{l}B C>0 \\
W C=0\end{array}$ & $\begin{array}{l}\mathrm{BC}=0 \\
W C>0\end{array}$ & $\begin{array}{l}B C>0 \\
W C>0\end{array}$ & Tolal \\
\hline $\begin{array}{l}\mathrm{BC}=0 \\
\mathrm{WC}=0\end{array}$ & 14.5 & 26.5 & 6.4 & 28.4 & 75.8 \\
\hline $\begin{array}{l}B C>0 \\
W C=0\end{array}$ & 1.8 & 5.8 & 0.6 & 7.6 & 15.8 \\
\hline $\begin{array}{l}B C=0 \\
W C>0\end{array}$ & 0.5 & 0.5 & 0.7 & 3.5 & 5.2 \\
\hline $\begin{array}{l}B C>0 \\
W C>0\end{array}$ & 0.3 & 0.6 & 0.1 & 2.2 & 3.2 \\
\hline Tolal & 17.1 & 33.4 & 7.8 & 41.7 & 100.0 \\
\hline
\end{tabular}

Table 5. Persistence in Employment Adjustment (percent of firms)

\begin{tabular}{|c|c|c|c|c|c|c|}
\hline \multirow[b]{2}{*}{1988} & \multicolumn{5}{|c|}{1990} & \multirow[b]{2}{*}{ Total } \\
\hline & $\begin{array}{c}\Delta \mathrm{E}<0 \\
\mathrm{H}=0\end{array}$ & $\begin{aligned} \Delta E & <0 \\
H & >0\end{aligned}$ & $\begin{array}{c}\Delta E=0 \\
H=0\end{array}$ & $\begin{array}{r}\Delta E=0 \\
H>0\end{array}$ & $\begin{array}{r}\Delta E>0 \\
H>0\end{array}$ & \\
\hline $\begin{array}{l}\Delta E<0, H=0 \\
\Delta E<0, H>0 \\
\Delta E=0, H=0 \\
\Delta E=0, H>0 \\
\Delta E>0, H>0\end{array}$ & $\begin{array}{l}1.3 \\
4.8 \\
0.6 \\
3.4 \\
3.6\end{array}$ & $\begin{array}{l}1.8 \\
6.0 \\
0.0 \\
4.8 \\
8.0\end{array}$ & $\begin{array}{l}0.0 \\
0.0 \\
0.0 \\
0.0 \\
0.0\end{array}$ & $\begin{array}{l}2.3 \\
4.9 \\
5.7 \\
6.8 \\
8.6\end{array}$ & $\begin{array}{r}2.3 \\
9.2 \\
3.5 \\
8.1 \\
14.3\end{array}$ & $\begin{array}{r}7.7 \\
24.9 \\
9.8 \\
23.1 \\
34.5\end{array}$ \\
\hline Total & 13.7 & 20.6 & 0.0 & 28.3 & 37.4 & 100.0 \\
\hline
\end{tabular}


Table 6. Estimates of the Flows in Figure 1, Netherlands, 1990 (percent of employment)

\begin{tabular}{ccccccc}
\multicolumn{2}{c}{ Hires } & Outflows & \multicolumn{3}{c}{ Intemal Flows } \\
\hline H & 11.9 & & & & \\
H1 & 3.2 & X & 10.1 & IM & 3.4 \\
H2 & 8.7 & & X2 & 8.2 & IM1 & 1.8 \\
& & & & & IM2 & 0.9 \\
& & & & IM3 & 0.4 \\
& & & & IM4 & 0.3 \\
\hline
\end{tabular}

Table 7. Estimates of (2), 1990 (percent of employnenit)

\begin{tabular}{lrcr} 
& Positive Part & Negative Part & Sum \\
\hline$\Delta \mathrm{E}$ & & & \\
$\Delta \mathrm{E}^{+}+\Delta \mathrm{E}^{-}$ & 4.0 & 2.2 & 1.8 \\
$\mathrm{~J}^{\mathrm{N}}+\mathrm{J}^{\mathrm{D}}$ & 4.4 & 2.6 & 6.2 \\
$\mathrm{H}+\mathrm{X}$ & 11.9 & 10.1 & 7.0 \\
& & & 22.0 \\
\hline
\end{tabular}

